\title{
Effects of Liming Acidic Soils on Improving Soil Properties and Yield of Haricot Bean
}

\author{
Adane Buni* \\ Ethiopian Institute of Agricultural Research, Holetta ARC, Addis Ababa, Ethiopia
}

\begin{abstract}
Field experiment was carried out in Sodo Zuria Woreda, Kutosorpelakebele on Nitisol loam soil with an inherent property of high Phosphorus fixation and acidity to study the influence of liming on reducing soil acidity and improving the desirable soil characteristics and grain yield of haricot bean. The treatments comprised four levels of lime $\left(0,1250,2500 \& 3750 \mathrm{~kg} \mathrm{ha}^{-1}\right)$. These were laid out in Randomized Complete Block Design with three replications. The results showed that soil pH increased from 5.03 to 6.72 by applying $3750 \mathrm{~kg} \mathrm{ha}^{-1}$ lime and the exchangeable acidity reduced significantly. Moreover, liming significantly $(P \leq 0.05)$ increased. Cation Exchange Capacity (CEC), available Phosphorus and decreased available micronutrients except $\mathrm{Cu}$. Grain yield showed a slight increment with an increase in the lime addition. Haricot bean yield was positively correlated with soil pH $(r=0.23), C E C(r=0.28)$ available phosphorus $(0.27)$ and negatively with the exchangeable acidity $(r=-0.37)$. This study stresses the importance of long-term lime experiments on major crops in order to investigate the residual effects and reduce lime costs.
\end{abstract}

Keywords: Lime; Soil acidity; Cation exchange capacity; Soil pH

\section{Introduction}

Soil acidity is a major constraint to cropping globally, especially in temperate and tropical regions of the world where high precipitation has been a dominant influence on the pedogenic development of the soil [1].

De la Fuente-Martinez and Herrera-Estrella [2] stated that approximately $43 \%$ of the world's tropical land area is classified as acidic, comprising about $68 \%$ of tropical America, $38 \%$ of tropical Asia, and $27 \%$ of tropical Africa.

In Ethiopia, vast areas of land in the western, southern and even the central highlands of the country which receive high rainfall are thought to be affected by soil acidity [3]. Currently, it is estimated that about $40 \%$ of the total arable land of Ethiopia is affected by soil acidity [4]. Of this land area, about $27.7 \%$ is moderately acidic ( $\mathrm{pH}$ in $\mathrm{KCl}) 4.5-5.5$ ) and about $13.2 \%$ is strongly ( $\mathrm{pH}$ in $\mathrm{KCl})<4.5$ ) acidic.

The causes of soil acidification have mainly been attributed to an imbalance in the carbon and nitrogen cycles [5-7]. These include (i) excretion of $\mathrm{H}^{+}$from plant roots to balance excess uptake of cations over anions; (ii) removal of large amounts of agricultural product, because both plant and animal produce are slightly alkaline; (iii) accumulation of organic matter, because it contains numerous acid functional groups from which these ions can dissociate [1]; (iv) mineralization and nitrification of plant $\mathrm{N}$ and consequent nitrate leaching and (v) input of acidifying substances as ammonium containing fertilizers. Precipitation also introduces acidity to soils, because gaseous carbon dioxide $\left(\mathrm{CO}_{2}\right)$ and water $\left(\mathrm{H}_{2} \mathrm{O}\right)$ in the rain react to form a solution that is about $\mathrm{pH} 5.7$ [8].

Soil acidity (or alkalinity) is measured in terms of $\mathrm{pH}$ which is the logarithm of the reciprocal of the hydrogen ion activity in solution, i.e. $\mathrm{pH}$ $=-\log \left[\mathrm{H}^{+}\right]$. The $\mathrm{pH}$ scale ranges from 0 to 14 . By definition, when soil $\mathrm{pH}$ falls below 7, it is deemed to be acidic, but many farm and soil managers do not usually consider a soil acidic until $\mathrm{pH} \mathrm{CaCl}_{2}$ falls below 5.5 .

In most acid soils with $\mathrm{pH}$ levels lower than 5.5 the major plant growth limitations are due to elemental toxicity mainly arising from $\mathrm{Al}$ and / or Mn [9]. Trace elements may also pose a toxicity threat if present at elevated levels as their availability and mobility increases under acidic conditions [10]. Deficiencies of essential nutrients such as $\mathrm{Ca}$, $\mathrm{Mg}, \mathrm{P}$ and Mo may also be involved [11]. Acidity of soils can decrease crop yield, seedling emergence and survival, legume nodulation and root growth [12].

Liming acid soil has been suggested as the best method to attain and maintain a suitable $\mathrm{pH}$ for the growth of a variety of crops [13]. Benefits of liming include improved nitrogen fixation and availability of essential nutrients $(\mathrm{Ca}, \mathrm{P}, \mathrm{Mo})$ and decreasing the solubility of toxic elements $\mathrm{Al}$ and $\mathrm{Mn}$ [14].

The overall reactions of lime in acid soil involve the dissolution of alkaline materials as they consume protons and consequently polymerize and precipitate ionic $\mathrm{Al}$ and $\mathrm{Mn}$. The neutralization of acidity by calcite (a major mineral in limestone) is shown in equations $1.1-1.4[15]$.

$$
\begin{aligned}
& \mathrm{CaCO}_{3}(\mathrm{~s})+6 \mathrm{H}^{+}(\mathrm{aq}) \rightarrow 3 \mathrm{Ca}^{2+}(\mathrm{aq})+3 \mathrm{CO}_{2}(\mathrm{~g})+3 \mathrm{H}_{2} \mathrm{O}(\mathrm{l}) \\
& 3 \mathrm{Ca}^{2+}(\mathrm{aq})+2 \mathrm{AlX}_{3}(\mathrm{ex}) \rightarrow 3 \mathrm{CaX}_{2}(\mathrm{ex})+2 \mathrm{Al}^{3+}(\mathrm{aq}) \\
& 2 \mathrm{Al}^{3+}(\mathrm{aq})+3 \mathrm{H}_{2} \mathrm{O}(\mathrm{l}) \rightarrow 2 \mathrm{Al}(\mathrm{OH})_{3}(\mathrm{~s})+6 \mathrm{H}^{+}(\mathrm{aq})
\end{aligned}
$$

Overall equation

$$
\underset{3 \mathrm{CO}_{2}(\mathrm{~g})}{3 \mathrm{CaCO}_{3}(\mathrm{~s})}+2 \mathrm{AlX}_{3}(\mathrm{ex})+\mathrm{H}_{2} \mathrm{O}(\mathrm{l}) 3 \mathrm{CaX}_{2}(\mathrm{ex})+\underset{(\mathrm{Eqn} 1.4)}{2 \mathrm{Al}(\mathrm{OH})_{3}(\mathrm{~s})+}
$$

The initial reaction (equation 1.1) results in a rapid increase in soil $\mathrm{pH}$ and ionic $\mathrm{Ca}$, as the active acidity is neutralized. As soil $\mathrm{pH}$ and ionic $\mathrm{Ca}$ increases the retention of $\mathrm{Ca}$ on the soil exchange complex is favoured and $\mathrm{Al}^{3+}$ is expelled into the soil solution (equation 1.3). The expelled $\mathrm{Al}^{3+}$ undergoes hydrolysis transforming to less available forms at higher $\mathrm{pH}$. The protons generated as $\mathrm{Al}^{3+}$ undergoes hydrolysis are consumed as calcite continues to dissociate.

*Corresponding author: Adane Buni, Ethiopian Institute of Agricultural Research Holetta ARC, P.O.Box 2003, Addis Ababa, Ethiopia, Tel: +251-924698894; E-mail abienem@gmail.com

Received October 13, 2014; Accepted November 09, 2014; Published November 16,2014

Citation: Buni A (2014) Effects of Liming Acidic Soils on Improving Soil Properties and Yield of Haricot Bean. J Environ Anal Toxicol 5: 248. doi: 10.4172/2161-0525.1000248

Copyright: ( 2014 Buni A, et al.. This is an open-access article distributed under the terms of the Creative Commons Attribution License, which permits unrestricted use, distribution, and reproduction in any medium, provided the original author and source are credited. 
Given the fact that acid soils are believed to affect the properties of the soil as a growing media for crops and the potential importance of liming to alleviate the constraint this study was conducted with the objective of examining the effects of liming on i) Reducing the excessive and toxic concentration of elements ii) Increasing the availability of deficient nutrients and iii) Improving the yield of haricot bean.

\section{Materials and Methods}

\section{Description of the study area}

The study was conducted on farmer's field in Sodo Zuria Woreda at Kuto Sorpela Kebele, Southern Ethiopia. The woreda is located at a distance of $383 \mathrm{~km}$, south of the capital Addis Ababa. Geographically, the woreda lies between latitudes of $6.51324^{\circ}-6.792815^{\circ}$ and longitudes of $37.595824^{\circ}-38.054911^{\circ}$ with altitudes ranging from $1880-1960$ meters above sea level. The mean annual temperature of the woreda ranges from $17.6-25^{\circ} \mathrm{C}$ and the average annual rainfall is about 1300 mm per year.

The dominant soils of the Wolayita area are reported to be Nitisols which are sesquioxidic and moderately to strongly acidic [3]. These soils have high clay content (35-50\%), homogenous, highly developed medium angular blocky structures, and are silty clay in texture.

\section{Lime requirement (lr)}

The lime recommendation on this study was based on the amount of exchangeable acidity measured by the lime requirement soil test.

$$
\operatorname{LR}\left(\mathrm{t}-\mathrm{CaCO}_{3} \mathrm{ha}^{-1}\right)=\text { factor } \mathrm{x} \mathrm{mmol}\left(\mathrm{Al}^{+3}+\mathrm{H}^{+}\right) / 100 \mathrm{~g} \text { soil }
$$

To avoid over liming, an adaptation factor was proposed that takes the $\mathrm{Al}$ sensitivity of crops into account:

Factor $=<1$ for Al-tolerant crops

$=1.0$ for moderately Al-tolerant crops

$=1.5$ for Al- sensitive crops

The above equation assumes that $\mathrm{Al}$ toxicity is eliminated and, for $\mathrm{Al}$-sensitive crops, it assumes that $\mathrm{Al}$ saturation is close to $0 \%$ [9]. In this study a factor of 1.5 was chosen as the crop is a leguminous crop sensitive to acidity and thus, the lime requirement of the studied soil was found to be:

$$
\mathrm{LR}\left(\mathrm{t}-\mathrm{CaCO}_{3} \mathrm{ha}^{-1}\right)=1.5 \times 1.67=2.5 \text { tones } / \mathrm{ha}
$$

Lime rates of $0,1250,2500,3750 \mathrm{~kg} /$ hawere applied with three replications each using randomized complete block design (RCBD). Calcium Carbonate $\left(\mathrm{CaCO}_{3}\right)$ was used as the source of lime and the whole doses of lime of the respective treatments were broad casted uniformly by hand and mixed in the top $15 \mathrm{~cm}$ soil layer two months before sowing on May 31, 2010.

The sowing was done on July 24, 2010. Haricot bean was raised on a $10 \mathrm{~m}^{2}(5 \mathrm{~m} \times 2 \mathrm{~m})$ plots, each having 5 rows with a uniform inter-row spacing of $40 \mathrm{~cm}$ and with a planting density of 50 plants /row. The crop was harvested on November 3, 2010.

Composite Soil samples were taken prior to lime application and after harvesting soil samples were taken from each plot with different lime rate treatments.

\section{Soil analysis}

Cation exchange capacity (CEC) of the soil was determined by extracting the soil with $1 \mathrm{~N}$ ammonium acetate at $\mathrm{pH} 7$ using 1:10 soil:extractant ratio. The ammonium-saturated samples were subsequently replaced by sodium $(\mathrm{Na})$ from a percolating sodium chloride solution. The excess salt was removed by washing with alcohol and the ammonium that was displaced by sodium was measured by Kjeldahl method [16]. Exchangeable acidity was extracted by shaking the soil samples with $1 \mathrm{M} \mathrm{KCl}$ for $2 \mathrm{hr}$ and determined by titration with $0.05 \mathrm{M} \mathrm{NaOH}$ using phenolphthalein as indicator [17]. Available micronutrients (Iron (Fe), Manganese (Mn), Zinc $(\mathrm{Zn})$, and Copper $(\mathrm{Cu})$ ) contents of the soils were extracted by diethylenetriaminepentaacetic acid (DTPA) method [18] and the contents of available micronutrients in the extract were determined by Atomic Absorption Spectrophotometer. Available Phosphorus was determined by shaking $1 \mathrm{~g}$ of air dry soil in $20 \mathrm{ml}$ of $0.5 \mathrm{M} \mathrm{NaHCO}_{3}$ ( $\mathrm{pH} 8.5$ ) for 30 minutes [19] followed by measuring the Phosphorus concentration in the solution by the colorimetric technique of Murphy and Riley (1962) [20].

\section{Statistical analysis}

Data obtained was subjected to analysis of variance at $1 \%$ and $5 \%$ level of significance using Statistical Analysis Software (SAS) version 9.0. Mean values and mean comparisons were calculated and a correlation analysis had been done to see the relationship between parameters.

\section{Result and Discussion}

The general physical and chemical properties of the soil prior to the application of the treatments and cropping are presented in Table 1

\section{Soil pH}

As expected, soil $\mathrm{pH}$ increased with increasing limestone application, irrespective of the rate of application. The soil $\mathrm{pH}\left(\mathrm{H}_{2} \mathrm{O}\right)$ values were significantly increased $(\mathrm{P} \leq 0.01)$ with increasing rates of lime.

Soil pH increased significantly from 5.03 in the plots without lime to 6.72 at the lime rate of $3750 \mathrm{~kg} \mathrm{CaCO}_{3} \mathrm{ha}^{-1}$ (Table 2). Responses of $\mathrm{pH}$ to lime application were also observed in tropical soils in several regions of the world [21] and in Ethiopia by Alemayehu (1999) and Desta (1987) [22,23].

The rise in $\mathrm{pH}$ and reduction of soil exchangeable acidity is associated with the presence of basic cations $\left(\mathrm{Ca}^{2+}\right.$ and $\left.\mathrm{Mg}^{2+}\right)[24]$ and anions $\left(\mathrm{CO}_{3}^{-2}\right)$ in lime that are able to exchange $\mathrm{H}^{+}$from exchange sites to form $\mathrm{H}_{2} \mathrm{O}+\mathrm{CO}_{2}$. Cations occupy the space left behind by $\mathrm{H}^{+}$on the exchange leading to the rise in $\mathrm{pH}$.

\section{Cation Exchange Capacity (CEC)}

The analysis of variance showed that liming had affected the CEC of the soil significantly $(\mathrm{P}<0.0001)$. All lime levels resulted in a

Table 1: Selected properties of the soil before liming.

\begin{tabular}{|c|c|}
\hline Soil characteristics & Values \\
\hline $\mathrm{pH}($ by $1: 2.5$ soil water ratio) & 5.01 \\
\hline Available $\mathrm{P}(\mathrm{ppm})$ & 6.3 \\
\hline CEC $\left(\mathrm{cmol}(+) \mathrm{kg}^{-1}\right)$ & 17 \\
\hline Exchangeable acidity $\left.\left(\mathrm{cmol}^{-1}\right) \mathrm{kg}^{-1}\right)$ & 1.67 \\
\hline Micronutrient $\left(\mathrm{mg} \mathrm{kg}^{-1}\right)$ & 1.67 \\
\hline $\mathrm{Fe}$ & 42.35 \\
\hline $\mathrm{Mn}$ & 71.28 \\
\hline $\mathrm{Zn}$ & 12.56 \\
\hline $\mathrm{Cu}$ & 0.38 \\
\hline
\end{tabular}




\begin{tabular}{|c|c|c|c|c|c|c|c|c|c|}
\hline Treatment & $\mathrm{pH}$ & CEC & Al & Ex.acid & Av.P & $\mathrm{Fe}$ & Mn & $\mathrm{Cu}$ & Zn \\
\hline Lime (kg/ha) & $\mathrm{Cmol}(+) \mathrm{kg}^{-1}$ & $\mathrm{Cmol}(+) \mathrm{kg}^{-1}$ & $\mathrm{Cmol}(+) \mathrm{kg}^{-1}$ & $\mathrm{mg} / \mathrm{kg}$ & $\mathrm{mg} / \mathrm{kg}$ & $\mathrm{mg} / \mathrm{kg}$ & $\mathrm{mg} / \mathrm{kg}$ & $\mathrm{mg} / \mathrm{kg}$ & $\mathrm{mg} / \mathrm{kg}$ \\
\hline 0 & $5.03 d$ & $19.18 d$ & $0.68 a$ & $0.97 a$ & $5.36 b$ & $41.96 a$ & $70.3 a$ & $0.37 d$ & $11.67 a$ \\
\hline 1250 & $5.64 \mathrm{c}$ & $25.21 \mathrm{c}$ & $0.56 b$ & $0.75 b$ & $6.70 \mathrm{a}$ & $33.77 b$ & $58.4 b$ & $0.77 b$ & $0.19 b$ \\
\hline 2500 & $6.14 b$ & $31.49 b$ & $0.33 c$ & $0.51 \mathrm{c}$ & $7.04 a$ & $25.04 b$ & $46.0 \mathrm{c}$ & $0.99 a$ & $9.78 \mathrm{c}$ \\
\hline 3750 & $6.72 a$ & $33.34 a$ & $0.24 \mathrm{c}$ & $0.36 c$ & $6.67 a$ & $19.01 \mathrm{c}$ & $34.5 \mathrm{~d}$ & $0.65 c$ & $9.75 \mathrm{c}$ \\
\hline LSD (5\%) & 0.014 & 0.738 & 0.13 & 0.21 & 0.94 & 0.390 & 4.520 & 0.0591 & 0.138 \\
\hline CV (\%) & 3.01 & 6.24 & 8.12 & 6.43 & 2.04 & 11.56 & 14.73 & 10.11 & 12.38 \\
\hline
\end{tabular}

"Means within a column followed by the same letter(s) are not significantly different from each other at $P \leq 0.05 \%$

significant increase in CEC over the control plots. Accordingly, the highest $\left(33.34 \mathrm{cmol}(+) \mathrm{kg}^{-1}\right)$ and the lowest $\left(19.18 \mathrm{cmol}(+) \mathrm{kg}^{-1}\right)$ values of CEC were observed under the highest lime treated and the control plots, respectively (Table 2).

The increase in CEC due to liming could be attributed to the change in $\mathrm{pH}$ and the release of the initially blocked is omorphous and interlayer substitional negative charge by deprotonation of the variable charge minerals and functional groups of humic compounds caused by $\mathrm{Ca}^{2+}$. The greater amount of negative charge available on the surfaces of these minerals results in the increase in CEC [25].

\section{Exchangeable acidity and alumunium}

Exchangeable acidity of the soil was significantly $(\mathrm{P} \leq 0.01)$ decreased with all increasing rates of lime. Liming with the highest rate ( $3750 \mathrm{~kg} \mathrm{CaCO}_{3} \mathrm{ha}^{-1}$ ) recorded the minimum value of exchangeable acidity and exchangeable almunium which reduced them to $0.36 \mathrm{cmol}$ (+) $\mathrm{Kg}^{-1}$ and $0.24 \mathrm{cmol}(+) \mathrm{kg}^{-1}$ respectively (Table 2 ). This decrease may be ascribed to the increased replacement of $\mathrm{Al}$ by $\mathrm{Ca}$ in the exchange site and by the subsequent precipitation of $\mathrm{Al}$ as $\mathrm{Al}(\mathrm{OH})_{3}$, as the soil was limed [26]. Moreover, an increase in soil $\mathrm{pH}$ results in precipitation of exchangeable and soluble $\mathrm{Al}$ as insoluble $\mathrm{Al}$ hydroxides thus reducing concentration of $\mathrm{Al}$ in soil solution [27].

\section{Available phosphorus}

Available Phosphorus showed an increasing trend with lime applications of $\mathrm{L}_{1}, \mathrm{~L}_{2}$ and $\mathrm{L}_{3}$ which are not significantly different from each other means (Table 2). Effect of liming on phosphate adsorption availability in acid soils was studied [28]. He concluded that the adsorption of phosphate by amphoteric soil surfaces generally decreased slowly as the $\mathrm{pH}$ increased from 4.0 to 7.0. He also stated that liming can increase phosphate availability by stimulating mineralization of soil organic phosphorus. However at the higher liming rates of $3750 \mathrm{~kg} / \mathrm{ha}$ the available P reduced to a mean value of $6.67 \mathrm{mg} / \mathrm{kg}$ (Table 1). similar results were obtained by other researchers. Bartlet and Picarelli (1973) [29] showed that the growth of maize was retarded by a deficiency of $\mathrm{P}$ due to liming, when liming was done to increase the $\mathrm{pH}$ to more than 6 .

\section{Micronutrients}

All limed plots showed a significant $(\mathrm{P}<0.0001)$ difference as compared to the unlimited plot in their available $\mathrm{Fe}, \mathrm{Mn}$ and $\mathrm{Zn}$ content, showing a decreasing trend with the addition of more lime. The maximum available contents observed at the unlimited plot were $41.96,70.30$ and $11.67 \mathrm{in} \mathrm{mg} / \mathrm{kg}$ and the minimum value at the highest liming rate of $3750 \mathrm{~kg} / \mathrm{ha}$ were 19.01, 34.55 and $9.75 \mathrm{mg} / \mathrm{kg}$ for Fe, $\mathrm{Mn}$ and $\mathrm{Zn}$ respectively (Table 2). However the available $\mathrm{Cu}$ showed inconsistent change with the increase in liming.

The Pritam and Rai [30] studied the effect of liming on the availability of iron and manganese on acid soil with wheat (var. Sonalika). They concluded that the available $\mathrm{Fe}$, exchangeable $\mathrm{Mn}$ and $0.01 \mathrm{M} \mathrm{CaCl}_{2}$ extractable $\mathrm{Mn}$ in the soil decreased significantly, which was due to precipitation of $\mathrm{Fe}$ and $\mathrm{Mn}$ as carbonates, oxides or hydroxides resulting from an increase in $\mathrm{pH}$.

The predominant species of $\mathrm{Zn}$ below $\mathrm{pH} 7.7$ is $\mathrm{Zn}^{++}$and above this $\mathrm{pH}$ the neutral species, $\mathrm{Zn}(\mathrm{OH})_{2}$ is predominant. The solubility of $\mathrm{Zn}$ is highly $\mathrm{pH}$ dependent and decreases 100 fold for each unit increase in $\mathrm{pH}$. Zinc deficiency induced in acid soils by excessive liming is in fact explained by this relationship. At low $\mathrm{pH}$ values, some $\mathrm{Zn}^{++}$may be present on the exchange complex of soils, but at higher $\mathrm{pH}$ values the concentration of $\mathrm{Zn}$ falls and very little $\mathrm{Zn}^{++}$is present on the exchange complex.

\section{Grain yield}

Lime applied did not significantly increase the grain yield above the control. However, a significant increase in yield will be expected in the next planting season due to the addition of lime. Follet et al. [31] reported that lime action is slow acting, of long duration and not conspicuous. Most studies [32,33] also showed a statistical grain yield increase when excess acidity was neutralized over time.

Haricot bean yield was positively correlated with soil $\mathrm{pH}(\mathrm{r}=0.23)$, CEC ( $\mathrm{r}=0.28)$ available phosphorus (0.59) and negatively with exchangeable acidity $(r=-0.37)$ (Table 3$)$.

Table 3: Correlation between selected soil properties and yield.

\begin{tabular}{|c|c|c|c|c|c|}
\hline & Yield & $\mathrm{pH}$ & CEC & EA & A \\
\hline Yield & 1 & & & & \\
\hline $\mathrm{pH}$ & 0.23 & 1 & & & \\
\hline $\mathrm{CEC}$ & 0.28 & $0.83^{*+*}$ & 1 & & \\
\hline $\mathrm{EA}$ & $-0.37^{*}$ & $-0.78^{*+*}$ & $-0.84^{*+*}$ & 1 & 1 \\
\hline $\mathrm{AP}$ & $0.59^{*+*}$ & $0.74^{*+*}$ & $0.81^{*+*}$ & $-0.81^{*+*}$ & 1 \\
\hline
\end{tabular}

"Significant at the $\leq 0.05,{ }^{* *} \leq 0.001$, and ${ }^{* * *} \leq 0.0001$ levels.

$\mathrm{EA}=$ Exchangeable acidity, $\mathrm{AP}=$ Available phosphorus

$\mathrm{CEC}=$ Cation Exchange Capacity

\section{Summary and Recommendations}

The study findings support the idea that liming ameliorates soil acidity and improves soil chemical property making it favorable for the crop growth. Further research would have been required on the same farmer field lime was applied in the next cropping season to observe a significant increase in grain yield.

Lime recommendations have to be as specific as possible, taking soils, crops, and climate as well as the financial position of farmers into account. Other alternatives should also be tried. Choice of acid-tolerant crop varieties and use of compost and farm manure may further reduce the amounts of lime required and make farming more attractive. The 
Citation: Buni A (2014) Effects of Liming Acidic Soils on Improving Soil Properties and Yield of Haricot Bean. J Environ Anal Toxicol 4: 248. doi: $10.4172 / 2161-0525.1000248$

findings of this research should be scaled up to be practiced at the farmer's level.

Lime recommendation should be developed for major crop types produced in the area and would be respondent to the change in soil $\mathrm{pH}$, as lime recommendation is crop specific.

Optimizing the lime requirement so that the lime is not over applied to the extent of reducing the availability of essential nutrients for crop growth and affordable by the subsistence farmers of the area is a potential research theme.

Socioeconomic (e.g. Cost-benefit) analysis would be vital as farmers adoption for lime application to their acidic soils is another challenge and they need to be convinced it will be worth investing in. Lime is a recent agriculture input, in Ethiopian context, which worsen the livelihood of smallholder farmers unless credit service or subsidy is facilitated; which also requires an in-depth research.

\section{Acknowledgements}

The author is grateful to the guidance of Dr. Taye Bekele, whom Ethiopia lost its prominent and senior soil researcher, who had been working until his last breath

\section{References}

1. Brady NC, Weil RR (2002) The nature and properties of soils. $13^{\text {th }}$ Edition, New Jersey: Prentice- Hall Inc, USA 960.

2. De la Fuente-Martinez JM, Herrera-Estrella L (1999) Advances in the understanding of aluminum toxicity and the development of aluminum-tolerant transgenic plants. Advances in Agronomy 66:103-120.

3. Mesfin A (1998) Nature and Management of Ethiopian soils. Alemaya University of Agriculture, Ethiopia 272

4. Taye B (2007) An overview of acid soils their management in Ethiopia pape presented in the third International workshop on water management (Wterman) project. Haramaya, Ethiopia.

5. Haynes RJ (1983) Soil acidification induced by leguminous crops. Grass and Forage Science 38: 1-11

6. Helyar KR, Porter WM (1989) Soil acidification, its measurement and the processes involved. In: Soil Acidity and Plant Growth (Ed Robson AD) Academic Press Australia, Sydney 365-382.

7. Porter WM, McLay CDA, Dolling PJ (1995) Rates and sources of acidification in agricultural systems of southern Australia. In: Plant Soil Interactions at Low pH. (Ed Date RA) Kluwer Academic Publishers, Netherlands 64: 75-83.

8. Crawford TW, Singh U, Berman H (2008) Solving Agricultural Problems Related to Soil Acidity in central Africa's great lakes region. An international center for soil fertility and agricultural development. CATALIST project report.

9. Prasad R, Power JF (1997) Soil Fertility management for sustainable agriculture. Lewis Publisher, Boca Raton, New York Printed-Hall Inc., USA 392.

10. Kabata-Pendias G, Terelak H, Pietruch C (2001) Impact of soil factors on Zn and $\mathrm{Cd}$ contents in potato tubers. Proceedings of $6^{\text {th }}$ International Conference on the Biogeochemistry of Trace Elements, Guelph, Canada.

11. Somani LL (1996) Crop production in acid soils. Agrotech Publishing Academy New Delhi 223

12. Marschner $H(2002)$ Mineral nutrition of higher plants. $2^{\text {nd }}$ edition, Academic Press, London 674.
13. Slattery WJ, Coventry DR (1993) Response of wheat, triticale, barley, and canola to lime on four soil types in north-eastern Victoria. Australian Journal of Experimental Agriculture 33: 609-618.

14. Haynes RJ, Ludeke TE (1981) Effect of lime and phosphorus application on concentration of available nutrients and on $\mathrm{P}, \mathrm{Al}$ and $\mathrm{Mn}$ uptake by two pasture legumes in an acid soil. Plant and Soil 62: 117-128.

15. Essington ME (2004) Soil and water chemistry, an integrative approach. CRC Press, Boca Raton, Florida, USA.

16. Chapman HD (1965) Cation exchange capacity. In: Methods of soil analysis American society of Agronomy 9: 891-901.

17. McLean EO (1965) Aluminum. In: Methods of Soil Analysis, Black CA (ed) Agron. Part II. Am Soc Agron, Madison, Wisconsin, USA 978-998.

18. Tan KH (1996) Soil sampling, preparation, and analysis. Marcel Dekker Inc New York, USA 68-78.

19. Olsen SR, Cole CV, Watanabe FS, Dean LA (1954) Estimation of available phosphorus in soils by extraction with sodium carbonate. USDA Department circular 939. Government Printing Office, Washington DC.

20. Murphy J, Riley JP (1962) A modified single solution method for the determination of phosphate in natural waters. Anal Chim Acta 27: 31-36.

21. Caires EF, Barth G, Garbuio FJ (2006) Lime application in the establishment of a no-till system for grain crop production in southern Brazil. Soil and Tillage Research 89: 3-12.

22. Alemayehu Taffesse (1999) Effects of liming on maize yield and soil reaction. In: Tadele G/Selassie and Sahlemedhin Serthu (eds.), Proceedings of the 4th Conference of the Ethiopian Society of Soil Science. Addis Ababa, Ethiopia 272

23. Beyene $D$ (1987) Effect of lime and $N$ and $P$ fertilizer application on grain yield of barley. Ethiopian Journal of Agricultural Science 9: 1-13.

24. Fageria NK, Baligar VC, Zobel RW (2007) Yield, Nutrient uptake and Soil chemical properties as influenced by liming and Boron application in a No-tillage system. Communication in Soil Science and Plant Analysis 38: 1637-1652.

25. Pionke HB, Corey RB (1967) Relationships between acidic aluminum and soil $\mathrm{pH}$, clay and organic matter. Soil Sci Soc Amer Proc 31: 749-752.

26. Havlin LJ, Beaton DJ, Tisdale LS, Nelson LW (1999) Soil Fertility and Fertilizers: An introduction to nutrient management. $6^{\text {th }}$ edition, New Jersey Prentice Hall Inc, USA.

27. Ritchie GSP (1989) The chemical behaviour of aluminium, hydrogen and manganese in acid soils. In: Robson AD (Ed.) Soil Acidity and Plant Growth. Academic Press, Marrickville, Australia 1-49.

28. Haynes RJ (1992) Effects of liming on phosphate availability in acid soils. Plant and Soil 68: 289-308.

29. Bartlet RJ, Picarelli CJ (1973) Availability of boron and phosphorus as affected by liming on acid potato soils. Soil Science 116: 73-83.

30. Pritam, Rai RN (1989) Effect of liming on the availability of iron and manganese in acid soils. Journal of the Indian Society of Soil Science 37: 433-434.

31. Follet RH, Murphy LS, Donahue RL (1981) Fertilizers and soil amendments. New York Prentice Hall Incorporation.

32. Fuentes JP, Bezdicek DF, Flury M, Albrechy S, Smith JL (2006) Microbia activity affected by lime in a long-term no-till soil. Soil and Tillage Research 88: 123-131.

33. Weisz R, Heiniger R, White J, Knox GB, Reed L (2003) Long-Term Variable Rate Lime and Phosphorus Application for Piedmont No-Till Field Crops. Precision Agriculture 4: 311-330. 